\title{
MERUMUSKAN KEMBALI MAKNA DAN STANDARISASI RIBA ; KAJIAN KONTEKSTUALISASI HADIS
}

\author{
Muhamad Ridwan Nurrohman \\ Program Pascasarjana UIN Sunan Gunung Djati Bandung \\ E-Mail: rnurrohman@gmail.com
}

\begin{abstract}
This article will discuss about usury in the hadith perspective. The goal is to know that usury is forbidden by Islam. In explaining the author takes a historical approach, and theologies understand the whole matan Hadith there. The results showed that there are many things that become the standard and size of usury-related buying and selling goods, borrow money, the exchange of goods, as well as to know the law devour usury or riba uses the results that it is haraam riba. Other history even talk about the actors of usury threatened by the Prophet. They are eaters of usury, the giver. the author, the two witnesses, they all got the same anathema, income from usury was not going to get a blessing from Allah., At which point the property will be bankrupt. The implication of this research is a must for every Muslim to be careful concerning any matter that there are elements of usury therein. By knowing the cause of usury, the kinds of usury, usury laws and the threat of perpetrators of usury, so for those who have fear of God I hope to get away.
\end{abstract}

Keywords: Law, Riba, Hadith.

\begin{abstract}
Abstrak
Artikel ini akan membahas tentang riba dalam perspektif hadis. Tujuannya untuk mengetahui bahwa riba itu dilarang oleh agama Islam. Dalam menjelaskannya penulis menggunakan pendekatan historis, dan teologisuntuk memahami seluruh matan hadiuis yang ada. Hasil penelitian menunjukkan bahwa ada banyak hal yang menjadi standar dan ukuran riba terkait jual beli barang, meminjam uang, tukar-menukar barang, serta untuk mengetahui hukum memakan riba atau menggunakan hasil riba bahwa riba itu hukumnya haram. Riwayat lainnya bahkan berbicara tentang pelaku-pelaku riba diancam oleh Nabi saw. Mereka adalah pemakan riba, pemberinya, penulisnya, kedua saksinya, mereka semua sama mendapat laknat, penghasilan dari riba itu tidak akan mendapat berkah dari Allah swt., sehingga pada suatu saat akan mengalami kebangkrutan harta.

Implikasi penelitian ini adalah keharusan bagi setiap muslim agar berhati-hati terkait segala hal yang ada terdapat unsur riba didalamnya. Dengan mengetahui penyebab riba, jenis-jenis riba, hukum riba serta ancaman pelaku riba, maka bagi mereka yang bertakwa kepada Allah semoga menjauhinya.
\end{abstract}

Kata Kunci: Hadis; Hukum; Riba

\section{A. PENDAHULUAN}

Sejarah riba, memang sejalan dengan sejarah ekonomi manusia. Hal yang lebih menarik, ia tidak pernah sejalan dengan aturan agama manapun. Tidak juga sejalan dengan norma kemanusiaan di era manapun. Namun praktik ini tetap saja lestari. Inilah hal yang membuat riba menjadi hal yang menarik untuk dikaji. Berbagai penulis telah menulis persoalan ini dengan berbagai sudut pandang dan pendekatan. Sejauh yang penulis temukan, kitab karya 'Abdul 'Adzim Jalal Abu Zaid adalah salah satu karya yang paling komprehensif dalam masalah ini. Fiqh ar-Riba: Dirasah Muqaranah wa Syamilah li Tathbiqat al-Mu'ashirah, memuat begitu banyak hal tentang riba. Sejak sejarah praktik riba lintas tempat dan masa, hingga mengupas secara luas tentang praktik-praktik keuangan modern yang terindikasi riba di dalamnya (atau dalam bahasa penulisnya, 'illat). Lalu apa yang ingin penulis tawarkan dalam makalah ini? Pertama, sudut pandang dan pendekatan yang dibuat agak berbeda. Alih-alih memasuki masalah ini dari sudut fiqh seperti yang dilakukan 'Abdul 'Adzim, penulis lebih memilih untuk mendekati masalah ini dari sudut hadis. Adakah standarisasi yang Rasulullah SAW tetapkan melalui sabda-nya? Jika "tidak ada" mengapa, lalu jika "ada" bagaimana?

Mengapa hal ini menjadi penting? Ketika Allah SWT telah menetapkan keharaman riba, misalnya dalam QS. Al-Baqarah: 275 yang secara eksplisit menyatakan, wa Ahallallahul-Bai'a wa Harramar-Riba'. Maka tentu posisi Rasulullah SAW sebagai Nabi; mufassir al-Quran yang paling pertama 
dan utama, mestilah memberikan penjelasan yang cukup tentang keharaman riba tersebut. Utamanya, tentang pada apa saja ia adalah riba, dan pada apa saja ia bukan riba. Atau dalam bahasa hari ini, standarisasi riba.

Untuk memahami maksud dari sabda beliau tentu saja dibutuhkan berbagai ilmu alat. Maka pengkajian secara bahasa dan penjelasan para syarih hadis, akan sangat dibutuhkan dalam kajian ini. Lalu untuk membuat hadis-hadis tersebut tidak hanya berada dalam tataran konsep pada ranah ajaran, maka upaya mencari "benang merah" atau kontekstualisasi terhadap penjelasan Rasulullah SAW tersebut, juga masih dibutuhkan.

Akan tetapi, karena permasalahan riba ini adalah salah satu masalah paling kompleks dalam kehidupan manusia, maupun dari segi teks keagamaan. Maka pengkajian dalam makalah ini hanya terkait beberapa masalah yang muncul, dan bersumber dari hadis. Adapun permasalahan dari sudut pandang tafsir, terlebih lagi fikih dan tathbiq-nya di zaman modern ini, maka penulis tidak memasukannya, secara mendalam, dalam makalah ini. Namun pada beberapa bagian deskriptif, yang mau tidak mau mesti dijelaskan, maka penulis membahasnya secara ringkas.

Namun, sebelum lebih jauh membahas hadis-hadis tentang riba, ada baiknya dijelaskan terlebih dahulu makna riba itu sendiri. Mengapa penting? Tentu saja untuk menyamakan persepsi awal, dan lebih jauh untuk memudahkan pembahasan yang akan disampaikan pada sub-bahasan berikutnya.

\section{B. PEMBAHASAN}

\section{Makna Riba}

Riba (رب) secara bahasa, memiliki makna

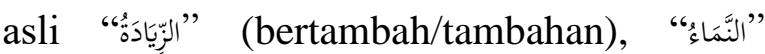
(tumbuh/berkembang), dan "العُعُلوُ (tinggi). ${ }^{1}$ Sedangkan dalam Lisan al-'Arab, Ibn

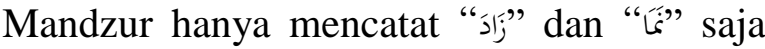

\footnotetext{
${ }^{1}$ Abi al-Husain Ahmad Faris bin Zakaria, Mu'jam Al-Maqayis Fi Al-Lughah, ed. by Abdussalam Muhammad Harun (Beirut: Darr al-Fikr, 1979). Disepakati pula olehMurtadha az-Zubaidi, Taj Al'Arus (Dar al-Hidayah), XXXVIII, p. 117.
}

sebagai makna aslinya. ${ }^{2}$ Jika diperhatikan lebih lanjut, perbedaan ini kelak akan berimplikasi terhadap pemahaman para ulama terhadap standarisasi riba.

Ketika riba diberikan makna asal al'Uluw, maka secara bahasa penambahan (ziyadah) itu tidak sekedar penambahan. Akan tetapi mesti memiliki sifat yang "tinggi", karena memang 'uluw adalah kebalikan dari as-Suflu; yang berarti paling rendah. $^{3}$ Mungkin inilah yang kelak mempengaruhi Yusuf $\mathrm{Ali}^{4}$ dan Muhamad Asad $^{5}$ ketika mengistilahkan riba sebagai usury (overcharge (tidak wajar/berlebihan), extortion (pemerasan) ${ }^{6}$; bunga yang tinggi) dan bukan interest (welfare (kesejahteraan), benefit (manfaat), profit (keuntungan) ${ }^{7}$; bunga yang rendah/wajar).

Sebagian lagi beralasan dengan menggunakan QS. Ali Imran: 130. Dalam ayat tersebut, Allah SWT secara tersurat menyebutkan:

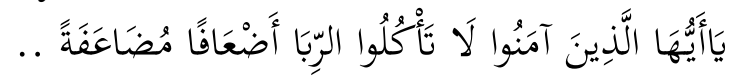

Artinya: "Wahai orang-orang yang beriman, janganlah kalian memakan riba yang berlipat ganda..."

Dari kalimat adh'afan-mudha'afan tersebut, ada yang memaknainya sebagai syarat. Dengan menempatkan kalimat tersebut sebagai syarat, maka jelas suatu tambahan yang sedikit tidak termasuk dalam riba yang diharamkan dalam ayat tersebut. Namun sayangnya, hal tersebut tidak didukung oleh mayoritas mufassir. ${ }^{8}$ Karena

\footnotetext{
${ }^{2}$ Muhammad bin Mukrim bin Mundzir al-Afriqiy Al-Masriy, Lisan Al-Arab (Beirut: Darr фadr). Diikuti pula olehMajma' (Dewan) Lugoh 'Arabiyyah, Mu'jam Al-Wasith. (kairo: Dar ad-Da'wah), I, p. 326.

${ }^{3}$ Ibn Duraid, Jamharatul-Lugoh, ed. by Ramzi Munir Ba'labaki (Beirut: Dar 'Ilm lil Malayin, 1987), II, p. 950.

${ }^{4}$ Yusuf Ali, The Holy Qur-an: English Translation of The Meanings and Commentary (Riyadh: King Fahd Holy Quran Printing Complex, 1405), p. 126.

${ }^{5}$ Muhammad Asad, "The Message Of The Quran; Translated And Explained,"(p. 847-848.) < www.islamicbulletin.org. $>$.

${ }^{6}$ Philip D. Morehead, The New American Webster Dictionary, 4th edn, 2001, p. 853.

${ }^{7}$ Philip D. Morehead.

${ }^{8} \mathrm{Al}$-Husain bin Muhammad Ar-Raghib alAsfahaniy, Tafsir Ar-Raghib Al-Asfahaniy, ed. by Dr.
} 
di kalangan pakar bahasa, kalimat adh'afanmudha'afan tersebut diposisikan sebagai hal. ${ }^{9}$ Maka otomatis sifat "berlipat ganda" itu hanya sebagai penjelasan kondisi yang pernah berlaku saja (yaitu riba nasi'ah yang telah berlaku sejak zaman jahiliyyah). ${ }^{10}$

Dari beberapa uraian di atas, maka dapat disimpulkan, bahwa riba tidak mesti suatu tambahan yang sangat besar (berlipat-ganda; usury). Karena makna al-'Uluw bahkan digunakan kepada setiap yang lebih tinggi dari yang seharusnya (bunga; interest). Maka setiap kelebihan, atau bahkan sekedar mengambil manfaat, dari setiap pinjaman yang diberikan, secara bahasa ia adalah riba, dan bahkan dihukumi haram. ${ }^{11}$ Pemaknaan tersebut dikuatkan pula melalui QS. AlBaqarah: 279, fa lakum ru'usu amwalikum, yang layak untuk diterima oleh pemberi pinjaman hanyalah pokok utangnya. Lalu dengan penutup ayat tersebut, la tadzlimun wa la tudzlamun (janganlah kamu menganiaya dan tidak pula menjadi yang dianiaya), telah menetapkan setiap tindakan tersebut adalah sebuah kedzaliman, dan haram untuk dipertahankan oleh ummat Islam.

\section{Sejarah Riba}

Ketika riba telah begitu mengakar dalam kegiatan ekonomi masyarakat Quraisy. Maka otomatis usaha untuk menghilangkannya pun tidak mudah. Oleh sebab itu, menarik kiranya jika memperhatikan sejarah pengharaman riba dalam al-Quran. Layaknya dalam kasus pengharaman khamr, fase-fase pengharaman ini juga terjadi untuk perilaku riba. Maka ketika kelak muncul perbedaan dari segi matn hadis, terkait penjelasan Rasulullah SAW soal riba, maka sangat memungkinkan ia mengikuti pola perubahan hukum ini.

'Adil bin 'Ali As-Syidi (Riyadh: Dar al-Wathan, 2003), III, p. 852.

${ }^{9} \mathrm{Abu}$ Ja'far an-Nuhhas, I'rab Al-Quran (Beirut: Dar al-Kutub al-'Ilmiyyah, 1421), I, p. 180.

${ }^{10}$ Mujahid bin Jabbar At-Tabi'i, Tafsir Mujahid, ed. by Dr. Muhammad 'Abdus-Salam (Dar al-Fikr alIslamiyyah al-Haditsah, 1989), I, p. 259

${ }^{11} \mathrm{M}$. Nejatullah Siddiqi, Issues in Islamic Banking: Selected Papers, trans. by Asep Hikmat (Bandung: Pustaka, 1984), pp. xiii-xv. Lihat juga, Al-Masriy.
Tahap pertama, Allah SWT menurunkan QS. Ar-Rum (30): 39, yang berbunyi:

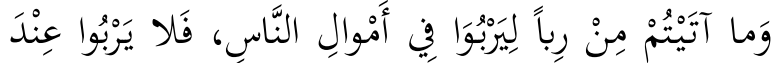

$$
\begin{aligned}
& \text { اللَّه }
\end{aligned}
$$

Artinya: "Dan sesuatu riba (tambahan) yang kamu berikan agar dia bertambah pada harta manusia, maka riba itu tidak menambah pada sisi Allah..." Dalam ayat yang dikategorikan ayat Makiyyah ini, kalimat riba disebutkan dalam konteks "pamrih" ketika memberikan bantuan kepada orang lain. ${ }^{12}$ Ayat ini sebagai permulaan proses pengharaman riba. Sekaligus sebagai sindiran dan isyarat, betapa pentingnya menjauhi hal tersebut. ${ }^{13}$

Tahap kedua, setelah memasuki fase Madaniyyah Allah SWT mengisahkan cerita tentang orang Yahudi. Ketika mereka telah melanggar aturan Allah SWT tentang riba. Maka Allah SWT menghukum mereka karena kemaksiatan mereka itu. Secara khusus Allah SWT memberikan peringatan tentang dosa riba ini dengan menurunkan QS. An-Nisa (4): 161, yang berbunyi:

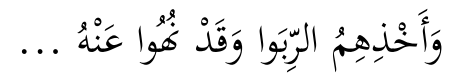

Artinya: "dan disebabkan mereka memakan riba, padahal sesungguhnya mereka telah dilarang daripadanya..." Dalam ayat ini, riba yang dimaksud bukan riba seperti dalam tema makalah ini. Riba dalam ayat ini berbicara dalam konteks

12 Lebih lanjut Ibn Abbas menjelaskan, riba ini adalah riba yang halal. Seseorang yang memberikan hadiah, dengan tujuan agar ia mendapatkan sesuatu yang lebih banyak dari orang yang ia beri. Maka pemberiannya itu tidak bernilai pahala, tidak juga diganjar dengan dosa. Akan tetapi hal tersebut haram hukumnya bagi Rasulullah SAW, secara khusus. Hal tersebut terindikasi dari QS. Al-Mudassir (74): 6 yang

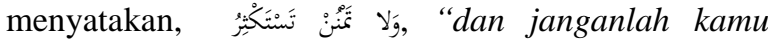
memberi (dengan maksud) ingin memperoleh (balasan) yang lebih banyak". (HR. Al-Baihaqi), Abu Bakar Ahmad bin al-Husain bin 'Ali al-Baihaqi, AsSunan Al-Kubra (Hyderabad: Majlis Da'irah alMa'arif an-Nizamiyah al-Ka'inah, 1344), VII, p. 81. Lihat juga, Yahya bin Salam, Tafsir Yahya Bin Salam, ed. by Dr. Hindun Syalabi (Beirut: Dar al-Kutub al'Ilmiyah, 2004), p. 661.

${ }^{13}$ Wahbah az-Zuhaili, Tafsir Al-Munir Fi Al'Aqidah Wa as-Syari'ah Wa Al-Manhaj (Damaskus: Dar al-Fikr al-Mu'ashir, 1418), VI, pp. 91-92. 
"harta haram", seperti uang sogok (risywah) dan ketika mereka (orang Yahudi) "menghalalkan" diri untuk mengambil harta orang Arab secara dzalim. ${ }^{14}$

Tahap ketiga, Allah SWT mulai berbicara secara langsung kepada ummat Islam terkait riba yang dimaksud dalam bab ini. Dalam tahapan ini Allah SWT menurunkan QS. Ali Imran (3): 130, yang berbunyi:

$$
\text { يا أَيْهُها الَّذِينَ آمَنُوا لا تَأْكُلُوا الَّبَوَا أَضْعافاً مُضاعَفَةً.... }
$$

Artinya: "Hai orang-orang yang beriman, janganlah kamu memakan riba dengan berlipat ganda..." Riba dalam ayat ini berbicara dalam konteks "Riba jahiliyyah", dengan pengkondisian "berlipat-ganda" (usury). Maka jikapun mereka yang "mengakali" pengharaman riba menggunakan ayat ini, maka hal itu akan terjawab dengan keterangan-keterangan yang datang berikutnya. Dengan ayat ini, terlihat Allah SWT telah menyampaikan pelarangan yang sharih, meskipun hanya sebagian kecil diantaranya saja; riba jahiliyyah. ${ }^{15}$

Tahap keempat, Allah SWT mulai mengharamkan seluruh jenis riba secara qath 'i. Dengan ini, Allah SWT menurunkan QS. Al-Baqarah (2): 275, yang berbunyi:

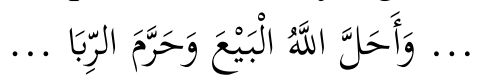

Artinya: “... dan Allah telah menghalalkan jual-beli dan mengharamkan riba..." Meskipun riba yang dibahas dalam ayat ini adalah setiap tambahan (kelebihan) dari pokok utang atau riba dayn. Namun jika diperhatikan lebih jauh, alif-lam yang terdapat dalam kata ar-Riba, dikategorikan oleh para mufassir menunjukkan makna lil jinsi. Maka yang Allah haramkan dengan ayat ini adalah semua jenis riba, tanpa terkecuali, yang kelak rinciannya akan dijelaskan melalui sabda Rasulullah SAW. ${ }^{16}$

14 Syamsuddin Al-Qurthubi, Al-Jami' Li Ahkam Al-Quran (kairo: Dar al-Kutub al-Mishriyyah, 1964), III, p. 348.

15 Wahbah az-Zuhaili, Tafsir Al-Munir Fi Al'Aqidah Wa as-Syari'ah Wa Al-Manhaj (Damaskus: Dar al-Fikr al-Mu'ashir, 1418), III, p. 92.

16 Wahbah az-Zuhaili, Tafsir Al-Munir Fi Al"Aqidah Wa as-Syari"ah Wa Al-Manhaj (Damaskus: Dar al-Fikr al-Mu'ashir, 1418), III, pp. 92-93.

\section{Riba Fadhl dan Nasiah dalam Sistem Bay' dan Dayn}

Secara umum, riba bisa terjadi pada dua kegiatan ekonomi, yaitu: jual-beli (bay') dan utang-piutang (dayn). Kedua kondisi ini dalam aturan fiqh, memiliki aturan hukum yang berbeda. Meski sama-sama dikategorikan sebagai transaksi yang haram, namun keduanya melalui proses hukum yang berbeda. Jika riba dayn, diharamkan oleh alQuran. Maka riba bay' diharamkan melalui proses hukum as-Sunnah. ${ }^{17}$

Hal yang membedakan riba bay' dan riba dayn, adalah karena ada komoditi barang yang ditentukan dalam batasan riba bay'. Sedangkan untuk riba dayn, tidak ada sedikitpun batasan, asalkan si pemberi pinjaman mengambil manfaat, baik besar ataupun kecil, dari si peminjam, maka itu telah dikategorikan sebagai riba yang haram. Setidaknya itulah yang disimpulkan oleh mayoritas Ulama.

Riba bay' (jual-beli) bisa terjadi dalam dua kondisi, yaitu: Fadhl, dan Nasiah. Fadhl, adalah ketika terjadi penambahan atau kelebihan pada salah satu dari 6 harta harta ribawi $^{18}$ sejenis, yang diperjual-belikan (bay') atau ditukarkan (barter). Sedangkan nasiah adalah ketika terjadi penundaan pembayaran (tidak cash), salah satu dari 6 jenis harta ribawi, yang diperjual-belikan atau ditukarkan hingga jatuh tempo.

Sedangkan dalam riba qardh, juga bisa tercakup dalam dua kondisi yang sama, yaitu: Fadhl, dan Nasiah. Fadhl, adalah ketika si peminjam mesti membayar lebih dari utang yang ia miliki (ra'sul-maal) atau dalam bahasa yang dikenal sekarang dengan bunga (interest dan usury). Dan semua riba dayn ini tergolong juga sebagai riba nasiah, karena

17 'Abdul 'Adzim Jalal Abu Zaid, Fiqh Ar-Riba: Dirasah Muqaranah Wa Syamilah Li Tathbiqat AlMu'ashirah (Beirut: Mu'assasah Risalah, 2004), p. 36.

18 Enam komoditi ini dijelaskan oleh Rasulullah SAW dalam sabdanya, "Emas ditukar dengan emas, perak dengan perak, gandum dengan gandum, terigu dengan terigu, kurma dengan kurma, garam dengan garam, harus sama beratnya dan tunai. Jika jenisnya berbeda maka juallah sekehendakmu tetapi harus tunai." (HR Muslim no 1210; At-Tirmidzi III/532; Abu Dawud III/248). 
semuanya muncul akibat "tempo" atau penangguhan. Dalam konteks utang, riba nasiah berupa tambahan (bunga) sebagai kompensasi atas tambahan tempo yang diberikan. Sementara itu, dalam konteks riba bay', riba nasiah tidak berupa tambahan, melainkan semata dalam bentuk penundaan penyerahan barang ribawi, yang sebenarnya disyaratkan harus tunai itu, baik keduanya sejenis maupun berbeda jenis. ${ }^{19}$

\section{Sejumlah Inkonsistensi Muhaddis tentang Riba}

Terkait riba, sebetulnya permasalahan terbesar terletak dari sisi perinciannya secara figh. Dalam hadis, permasalahan intinya ada pada 3 hal. Ketiga masalah tersebut sebenarnya kembali lagi pada fiqh para sahabat, yang tercatat dalam beberapa kitab hadis, baik syarah maupun matn. Adapun tiga masalah tersebut adalah:

a. Kategorisasi dalam riba dayn

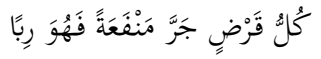

Sepanjang penelusuran penulis dalam kitab-kitab matn dan syarah hadis, tidak ditemukan satupun riwayat yang bersambung kepada Rasulullah SAW terkait teks tersebut. Namun menariknya, adalah penggunaan para syarih hadis terhadap teks tersebut, begitu bertebaran dalam berbagai kitab. Penisbatan yang disampaikan oleh para Ulama pun, telah memberikan kesan bahwa tidak ada masalah apapun terkait teks acuan tersebut. Tercatat nama seperti Imam al-Khatthabi ${ }^{20}$, Ibn Mulaqqin $^{21}$, Ibn Baththal ${ }^{22}$, at-Thibi ${ }^{23}$, Ibn Rajab $^{24}$, dan al-'Aini ${ }^{25}$ bahkan menggunakan

19 'Abdul 'Adzim Jalal Abu Zaid

${ }^{20}$ Abu Sulaiman al-Khatthabi, Ma'alim as-Sunan (Halb: al-Mathba'ah al-'Ilmiyyah, 1932), III, p. 141.

${ }^{21}$ Ibn Mulaqqin as-Syafi'i, At-Taudih Li Syarhi Jami' as-Shahih (Damaskus: Dar an-Nawadir, 2008), XIV, p. 160.

${ }^{22}$ Ibn Baththal al-Maliki, Syarh Shahih Al-Bukhari (Riyadh: Maktabah ar-Rusyd, 2003), VI, 515.

${ }^{23}$ Al-Husain bin 'Abdullah At-Thibi, Al-Kasyif 'an Haqaiq as-Sunan (Riyadh: Maktabah Nizar Musthafa al-Baz, 1997), vII, p. 2155

${ }^{24}$ Ibn Rajab al-Hanbali, Fath Al-Bari Syarh Shahih Al-Bukhari (Madinah: Maktabah al-Ghuraba alAsariyyah, 1996), III, p. 356. hadis ini sebagai pertimbangan nasikh, dan bahkan untuk menghukumi fasid kepada beberapa hadis lain yang bertentangan dengan makna hadis ini.

Arah pembahasan baru berubah di tangan Ibn Hajar al-Asqalaniy dan as-Shan'ani. Kedudukan hadis ini mulai didiskusikan. Ibn Hajar mengomentari hadis ini, dengan sanad dari Ali bin Abi Thalib, dihukumi sebagai sanad yang sâqit (gugur). Akan tetapi, hadis ini memiliki syahid meski dengan derajat dhaif, dari Fadhalah bin 'Ubaid dalam riwayat al-Baihaqi. ${ }^{26}$ Terakhir, hadis ini didukung oleh sebuah atsar mauquf yang bersumber dari Abdullah bin Salam dalam riwayat al-Bukhari. ${ }^{27}$

Untuk yang terakhir, as-Shan'ani menyatakan bahwa ia tidak menemukan atsar tersebut dalam bab al-Istiqrad. Dalam artian, beliau mengingkari keberadaan atsar yang disebutkan oleh Ibn Hajar ini. Beliau merujuk kepada penjelasan Ibn Hajar dalam Talkhis al-Habir. ${ }^{28}$ Dalam kitab tersebut, Ibn Hajar memang tidak men-takhrij dari Bukhari, akan tetapi dari atsar-atsar mauquf beberapa sahabat, dalam riwayat al-Baihaqi pada kitab Sunan al-Kubra. ${ }^{29}$

Namun setelah penulis teliti lebih lanjut, kebaradaan atsar mauquf tersebut benarbenar ada dalam Shahih al-Bukhari. Namun bukan dalam bab al-Istiqrad seperti yang dibayangkan oleh as-Shan'ani. Akan tetapi dalam Manaqib Abdullah bin Salam. Lebih jelasnya penulis kutipkan di bawah ini:

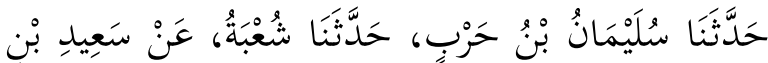

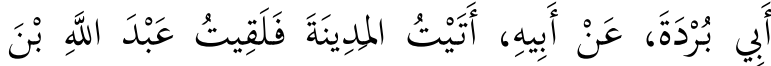

${ }^{25}$ Badruddin Al-'Aini, Umdah Al-Qari Syarh Shahih Al-Bukhar (Beirut: Dar Kutub al-'Ilmiyyah, 2001), XII, p. 150

26 Abu Bakar al-Baihaqi, Ma'rifat as-Sunan Wa Al-Atsar (kairo: Dar al-Wafa, 1991), VIII, p. 168.

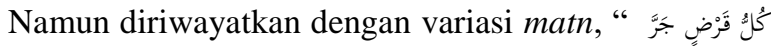

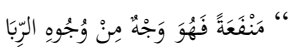

${ }^{27}$ Ibn Hajar al-Asqalaniy, Bulugh Al-Maram Min Adillatil-Ahkam (Riyadh: Dar al-Falaq, 1424), p. 253.

${ }^{28}$ Muhammad bin Ismail as-Shan'ani, Subulus Salam (Riyadh: Maktabah al-Ma'arif, 2006), III, pp. 127-28.

29 Ibn Hajar Al-Asqalaniy, Talkhis Al-Habir (Bairut: Dar al-Kutub al-'Ilmiyyah, 1989), III, p. 90. 


$$
\begin{aligned}
& \text { سَلاَمٍ رَضِيَ اللَّهُ عَنْهُ، فَقَالَ:(أَلا بَتِيَيءُ فَأُطْعِمَكَ سَوِيقًا }
\end{aligned}
$$

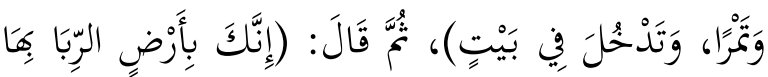

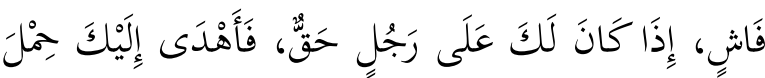

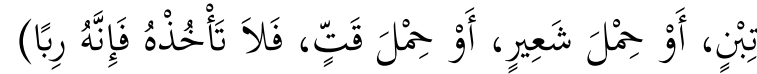

Artinya: Aku (Abu Burdah) mengunjungi Madinah lalu bertemu dengan 'Abdullah bin Salam RA. Aku berkata, "Tidakkah sebaiknya engkau berkunjung ke rumahku, nanti kusuguhi makanan terbuat dari tepung dan kurma, dan kamu masuk ke dalam rumah." Kemudian dia ("Abdullah bin Salam) berkata, "Sungguh kamu sekarang berada di negeri dengan praktek riba sudah merajalela. Jika kamu bersama seseorang yang bisa dipercaya, kemudian ia menghadiahkan kepadamu buah tin, gandum atau biji-bijian, maka janganlah kamu mengambilnya karena itu adalah riba", ${ }^{30}$

Maka dengan itu, penisbatan ini bisa dianggap benar, kepada Abdullah bin Salam, maupun para sahabat yang lainnya. Meskipun sangat sulit untuk memastikan ketersambungannya kepada Rasulullah SAW. Namun setidaknya, sejauh ini, bisa dikatakan batasan ini telah menjadi konsesus di kalangan para sahabat, dan juga para Ulama setelahnya. Bahkan telah dipraktekkan dalam kehidupan mereka. ${ }^{31}$

Namun sebenarnya ada pendapat lain dalam memaknai jarra-manfa'at dari utang (qardin) yang diberikan itu, hanya berstatus makruh saja, bukan riba. ${ }^{32}$ Ada kemungkinan, hal tersebut disebabkan mereka menemukan hadis-hadis yang menganjurkan "mengembalikan utang" dengan sesuatu yang lebih baik. Hadis tersebut diantaranya:

$30 \mathrm{Abu}$ 'Abdullah Muhammad bin Isma'il alBukhari, Al-Jami' Al-Sahih, ed. by Musthafa Dib (Beirut: Darr Ibnu Katsir, 1987), V, p. 38.

${ }^{31}$ Misalnya kisah Imam Abu Hanifah, yang tidak ingin berdiam di bawah naungan pohon dari orang yang berhutang kepadanya. Lihat, Abdul-Karim AlQusyairi, Ar-Risalah Al-Qusyairiyyah (Bairut: Dar alMa'arif), I, p. 230.

32 Mereka yang berpendapat demikian adalah: Ibrahim, al-Hasan, Muhammad, dan 'Atha. Hal ini tercatat dalam Mushannaf Ibn Abi Syaibah dan Mushannaf 'Abd ar-Razzaq.

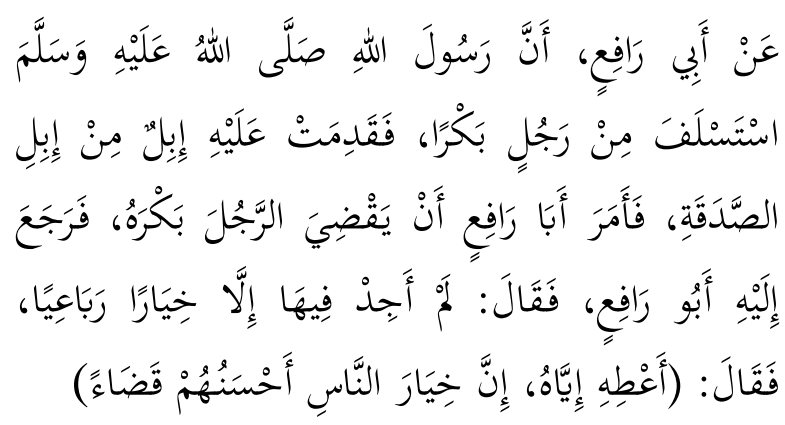

Artinya: Dari Abu Rafi', bahwa Rasulullah SAW pernah meminjam unta muda dari seorang laki-laki, ketika unta sedekah tiba, maka beliau pun memerintahkan Abu Rafi' untuk membayar unta muda yang dipinjamnya kepada laki-laki tersebut. Lalu Abu Rafi' kembali kepada beliau seraya berkata, "Aku tidak mendapatkan unta muda kecuali unta yang sudah dewasa." Beliau bersabda: "Berikanlah kepadanya, sebaikbaik manusia adalah yang paling baik dalam membayar hutang. "33

Maka dari hadis tersebut, sebenarnya para syarih telah menjelaskan keterkaitan keduanya. Lalu dalam keterangan Ibn Mandzur, dibagilah riba ini menjadi 2 macam. Riba yang haram, dan riba yang halal. ${ }^{34}$ Maksudnya, jika ia disyaratkan dalam akad pinjam-meminjam untuk memberikan tambahan, maka ia dihukumi haram. Namun jika hal tersebut diberikan secara suka-rela oleh peminjam, tanpa disyaratkan oleh yang meminjamkan, maka ia dihukumi halal, atau bahkan dianjurkan oleh Rasulullah SAW. ${ }^{35}$

b. Para Sahabat berbeda pendapat tentang rincian riba

Sepanjang penelusuran penulis, para sahabat tidak pernah berbeda pandangan mengenai keharaman riba. Namun tentang apa saja yang tergolong sebagai riba, ketika itulah para sahabat pernah berbeda pandangan. Mengapa penulis katakan pernah

\footnotetext{
${ }^{33}$ Muslim bin al-Hajjaj Abu al-Husain al-Qusyairiy al-Naisaburiy, Shohih Muslim, ed. by Muhammad Fuad Abdul Baqiy (Darr Ihya al-Turats al-Arabiy), III, p. 1224.

${ }^{34}$ Ibn Muhammad bin Mukrim bin Mundzir alAfriqiy Al-Masriy, Lisan Al-Arab (Beirut: Darr cadr),XIV p. 304.

35 Muhammad bin Ismail as-Shan'ani, Subulus Salam (Riyadh: Maktabah al-Ma'arif, 2006), III, p. 128.
} 
terjadi perbedaan pendapat? Karena hal tersebut memang tercatat dalam berbagai kitab Hadis. Misalnya saja dalam hadis di bawah ini:

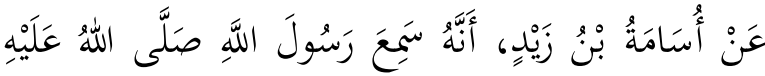

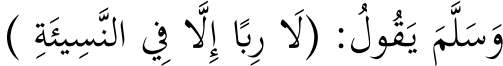

Artinya: Dari Usamah bin Zaid, bahwasanya ia pernah mendengar Rasulullah SAW bersabda, "Tidak ada riba, kecuali riba nasiah (pada penangguhan). "36 Hadis lainnya menjelaskan:

$$
\begin{aligned}
& \text { عَنْ أُسَامَةَ بْنْ زيِْْد، أَنَّ رَسُولَ اللَّهِ صَلَّى اللهُ عَلَيْْهِ وَسَلَّمَ } \\
& \text { قَّالَ: (لَا رِبًا فِيمَا كَانَ يَلًِا بِيَدِد) }
\end{aligned}
$$

Artinya: Dari Usamah bin Zaid, bahwasanya Rasulullah SAW bersabda, "Tidak ada riba pada sesuatu (jual-beli) yang dilakukan secara tunai., 37 Dalam riwayat yang lain, diceritakan juga Ibn Abbas bahkan pernah terpengaruhi oleh ucapan Usamah bin Zaid ini. Bahkan pernah satu waktu $\mathrm{Abu}$ Sa'id al-Khudri meminta konfirmasi kepada Ibn Abbas terkait hal itu, karena sepengetahuan Abu Sa'id, Rasulullah SAW pernah menyampaikan:

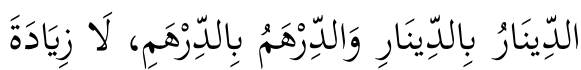

Artinya: "(Utang satu) Dinar dibayar (satu) dinar, (satu) dirham dibayar (satu) dirham, tidak ada tambahan padanya." 38 Maka jawaban Ibn Abbas saat itu, "Aku tidak menemukannya (riba selain nasiah) dalam al-Quran, tidak juga mendengarnya dari Rasulullah SAW. Aku hanya mendengar bahwa Usamah berkata demikian." Dilihat dari kasus-kasus ini, sebetulnya wajar jika

${ }^{36}$ Sanad hadis ini shahih. Hadis ini dicatat dalam Musnad karya Imam Ahmad, jilid. 5, 202. Juga dalam riwayat at-Thabrani dalam Mu'jam al-Kabir, no. 449. Lihat, Ibn Syahin Umar bin Ahmad, Nasikh Al-Hadis Wa Mansukhihi, ed. by Sumair bin Amin Az-Zuhairi (Maktabah al-Manar, 1988), p. 381.

${ }^{37}$ Ibn Syahin Umar bin Ahmad, p. 381.

38 Dalam riwayat yang lain, Abu Sa'id bahkan memastikan, setiap tambahan dan pengurangan di dalamnya, maka itu adalah riba. misalnya Ibn Qayyim mengistilahkan riba nasiah, sebagai riba jali (terang-terangan). ${ }^{39}$

Dalam riwayat lain, Abul-Jauza pernah bertanya kepada Ibn Abbas, tentang barter secara tunai. Maka Ibn Abbas menjawab, "Tidak apa-apa. Meskipun engkau menukar dua dengan satu, atau bahkan dengan jumlah yang lebih banyak atau lebih sedikit." Kemudian aku melakukan ibadah haji di lain waktu, dan ketika itu Syaikh (Ibnu Abbas) masih hidup, lalu aku pun mendatanginya dan bertanya kepadanya tentang barter ini, maka ia menjawab, "Mestilah sebanding." Abul-Jauza berkata, "Bukankah dahulu engkau telah memberiku fatwa bahwa dua dengan satu, dan aku telah memberikan fatwa seperti itu semenjak engkau memberitahuku fatwa itu." Maka iapun berkata, "yang aku katakan tempo dulu adalah berdasarkan pendapatku sendiri, dan Abu Sa'id telah menceritakan dari Rasulullah SAW, maka aku pun tinggalkan pendapatku dan berpegang dengan hadits dari Rasulullah SAW."40

Dari riwayat ini, diketahui bahwa ada sebuah perubahan fatwa Ibn Abbas, hal tersebut dipengaruhi oleh informasi yang tidak merata diterima para sahabat. Maka dengan penyesalan yang besar, Ibn Abbas bertaubat dan ingin berlepas-diri dari pendapat tersebut. Setelah pengakuan ini, maka siapapun tidak berhak untuk merujuk kepada Ibn Abbas terkait pemikiran tersebut. $^{41}$ Itulah sebagian perbedaan pendapat yang terjadi di kalangan para sahabat, yang terekam dalam kitab hadis.

c. Tidak ada rincian riba yang langsung dijelaskan Rasulullah SAW

Setelah ditelusuri berbagai riwayat terkait riba, akhirnya ditemukanlah bahwasanya Rasulullah SAW memang tidak sempat merinci praktek apa saja yang termasuk pada riba, secara utuh. Keterangan tersebut

${ }^{39}$ Ibn al-Qayyim Al-Jauziyyah, I'lam AlMuwaqqi'in 'an Rabbil- 'Alamin (Beirut: Dar al-Kutub al-'Ilmiyyah, 1991), II, p. 103.

40 Ahmad bin Hanbal, MUSNAD AHMAD BIN HANBAL, ed. by Syu'aib Al-Arnauthiy (Mu'assasah Risalah, 1999), p. 57.

${ }^{41}$ Ibn Syahin Umar bin Ahmad, p. 390. 
dikisahkan oleh Umar bin Khatthab. Seperti dalam riwayat di bawah ini:

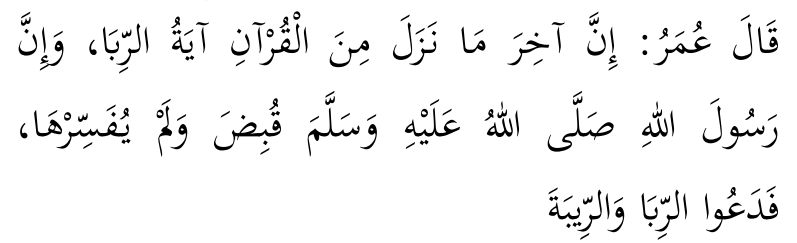

Artinya: Umar berkata, "Sesungguhnya diantara ayat al-Quran yang turun paling akhir adalah ayat riba. Dan sesungguhnya Rasulullah SAW wafat, tanpa sempat menafsirkannya. Maka jauhilah oleh kalian riba dan hal-hal yang meragukan (terindikasi riba padanya; sebagai kehatihatian)" ${ }^{42}$

Fu'ad 'Abd al-Baqi, menjelaskan dalam ta'liq-nya dalam Sunan Ibn Majah, bahwa yang dimaksud dengan "tidak sempat menafsirkan" dalam hadis ini adalah sebuah penafsiran yang utuh, dengan merinci setiap bagian-bagian kecilnya, sehingga ummat Islam tidak perlu lagi direpotkan dengan melakukan qiyas. ${ }^{43}$ Keharaman riba, sebagai sebuah status hukum, tidak ada seorangpun yang menyangkalnya. Keburukannya pun telah dikenal oleh semua agama dan peradaban manusia. Namun ketika masuk dalam perincian, maka dalam hal itu telah terjadi khilaf di dalamnya. Tentu sesuatu yang wajar, karena hal tersebut merupakan ranah ijtihad, yang tidak datang nash qath'i tentangnya. Namun yang lebih penting adalah anjuran Umar dalam akhir riwayat di atas. Maka jauhilah oleh kalian riba dan halhal yang meragukan (terindikasi riba padanya; sebagai kehati-hatian).

\section{Jalan Keluar dari Riba; Sejumlah Penawaran}

Karakteristik Islam yang selalu mengubah segala keburukan dari dasarnya, setidaknya mestilah memberikan sebuah dorongan semangat untuk ber-ijtihad. Islamisasi Ekonomi yang ditawarkan M. Nejatullah

${ }^{42}$ HR. Ahmad, jilid. 1, 361. Sanad-nya berstatus hasan. HR. Ibn Majah, jilid. 2, 764. Sanad-nya berstatus shahih oleh al-Albani.

${ }^{43} \mathrm{Abu}$ 'Abdullah Muhammad bin Yazid AlQazwaini, Sunan Ibn Majah, ed. by juz II qiq Muhammad Fu'ad 'Abd al-Baqi (Beirut: Dar al-Fikr), II, p. 764.
Siddiqi, dengan mengubah cara pandang (worldview) kapitalistik dengan sistem bunga-nya, melalui sistema bagi-hasil; musyarakah. Sudah semestinya menjadi hal yang perlu dipertimbangkan dan disempurnakan. Islam dalam penentangannya kepada praktik riba, sebenarnya ini mengajarkan cara hidup bersosial yang benar. Bahwa segalanya tak hanya soal tambah dan kurang. Namun juga dengan bagi dan kali. Kehidupan sosial yang sehat, menurut Islam, adalah mereka yang menggunakan asas tolong-menolong. Bukan malah asas hedonis-materialistis, dan selalu mengedepankan hitung-hitungan matematis kapitalistik.

Dari syariat riba yang dibahas pada makalah ini menunjukkan. Bahwa Islam harus selalu mengedepankan jiwa ikhlas dan hanya mengharap balasan dari Allah SWT. Memberikan bantuan tanpa pamrih. Upaya pemerataan kehidupan ekonomi di masyarakat. Tidak memperbesar jurang pemisah antara si miskin dan si kaya. Adalah beberapa hikmah dan tujuan nyata dari pengharaman riba. Karena hukum Allah memang bukan untuk diakali. Namun tidak ada salahnya jika kita menjalankan yang telah ada dahulu, bi dharurah, karena memang ma laa yudroku kulluhu fa laa yutroku kulluhu. Maka sebagai langkah awal, setidaknya kita mulai hijrah menuju Bank Syari'ah, yang memang belum sempurna. Namun setidaknya telah ada upaya menuju hal tersebut. Karena Allah SWT tentu sangat menghargai upaya kita, sedangkan untuk keputusan akhir, biarlah kepada Allah saja kita memohon pertolongan.

Tawaran yang diberikan oleh $M$. Nejatullah Siddiqi, tentu juga belum sempurna, dan mungkin masih terkesan utopis. Akan tetapi hal tersebut tentu bukan hal yang mustahil. Islam memiliki potensi besar di bidang ekonomi syari'ah, karena bahkan dalam lingkungan itulah Islam benarbenar "menghidupkan". Selain itu, Islam juga masih memiliki sistem zakat. Sehingga tidak akan ada lagi seharusnya orang-orang yang terpaksa meminjam kepada rentenir untuk kebutuhan makan sehari-hari misalnya. Lalu apa masalahnya? Karena kita, ummat Islam, 
belum bisa memiliki keyakinan terhadap syumuliyah-nya Islam. Agama hanya ditempatkan di tempat ibadah, dan hari keagamaan saja. Bukan diaplikasikan secara massif dalam setiap sendi dan poros kehidupan.

\section{SIMPULAN}

Ridha tidak menghalalkan Riba. Mengapa? Karena hukumlah yang membatasi kerelaan. Dalam artian ketika seseorang dengan rela melanggar hukum, maka jelas sang pembuat hukum tidak akan pernah rela terhadap perbuatannya itu. Ketika sepasang laki-laki dan perempuan rela sama rela untuk berzina, misalnya, apakah zina tersebut menjadi halal? Jelas ini hal yang tidak dibenarkan dalam logika hukum.

Lalu apakah dzalim adalah 'illat dari Riba? Ya! Akan tetapi, ukuran kedzaliman ini sebenarnya telah ditetapkan dalam alQuran secara tersirat. Mengambil keuntungan dari orang yang kesusahan, jelas hal yang tidak bisa dibenarkan meski dengan jiwa kemanusiaan sekalipun. Lalu bagaimana soal saling-membantu dalam urusan bisnis? Jelas Islam memiliki berbagai solusi bagi-hasil yang telah dijelaskan dalam setiap bab fiqh iqtishadiyyah. Tentu dengan aturan tersendiri, masing-masing, yang juga telah banyak dibahas oleh para ahlinya.

Apakah adh'afan mudha'afan adalah 'illat (atau syarat) dalam pengharaman riba? Jika dilihat dari makna dasar, dan siyaq al-Quran ketika membahasakan kalimat tersebut. Bisa dilihat ternyata ia bukan sebagai illat hukum "haram" bagi riba. Tapi justru berdiri pada posisi hal, dengan konsekuensi hukum sebagai penjelasan fase tahrim sharih juz-i bagi praktek riba.

Kemudian kesimpulan terakhir bisa disimpulkan, bahwa riba secara hukum memang telah pasti. Namun untuk rinciannya, ia adalah ranah ijtihadi. Hal tersebut dapat dirujuk dalam berbagai kitab fiqh yang membahas tentang utang, jual-beli, dan berbagai praktek ekonomi lainnya.

\section{DAFTAR PUSTAKA}

'Abdul 'Adzim Jalal Abu Zaid, Fiqh Ar-
Riba: Dirasah Muqaranah Wa Syamilah Li Tathbiqat Al-Mu'ashirah (Beirut: Mu'assasah Risalah, 2004)

Abu 'Abdullah Muhammad bin Isma'il alBukhari, Al-Jami' Al-Sahih, Juz II, ed. by Musthafa Dib (Beirut: Darr Ibnu Katsir, 1987)

Abu Bakar Ahmad bin al-Husain bin 'Ali alBaihaqi, As-Sunan Al-Kubra (Hyderabad: Majlis Da'irah al-Ma'arif an-Nizamiyah al-Ka'inah, 1344), VII

Abu Bakar al-Baihaqi, Ma'rifat as-Sunan Wa Al-Atsar (kairo: Dar al-Wafa, 1991), VIII

Abu Ja'far an-Nuhhas, I'rab Al-Quran (Beirut: Dar al-Kutub al-'Ilmiyyah, 1421), I

Abu Sulaiman al-Khatthabi, Ma'alim asSunan (Halb: al-Mathba'ah al'Ilmiyyah, 1932), III

Ahmad bin Hanbal, MUSNAD AHMAD BIN $H A N B A L$, ed. by Syu'aib Al-Arnauthiy (Mu'assasah Risalah, 1999)

Al-'Aini, Badruddin, Umdah Al-Qari Syarh Shahih Al-Bukhar (Beirut: Dar Kutub al-'Ilmiyyah, 2001), XII

Al-Asqalaniy, Ibn Hajar, Talkhis Al-Habir (Bairut: Dar al-Kutub al-'Ilmiyyah, 1989), III

Al-Husain bin Muhammad Ar-Raghib alAsfahaniy, Tafsir Ar-Raghib AlAsfahaniy, ed. by Dr. 'Adil bin 'Ali AsSyidi (Riyadh: Dar al-Wathan, 2003), III

Al-Jauziyyah, Ibn al-Qayyim, I'lam AlMuwaqqi'in 'an Rabbil-'Alamin (Beirut: Dar al-Kutub al-'Ilmiyyah, 1991), II

Al-Masriy, Muhammad bin Mukrim bin Mundzir al-Afriqiy, Lisan Al-Arab (Beirut: Darr cadr)

Al-Qazwaini, Abu 'Abd al-Lah Muhammad bin Yazid, Sunan Ibn Majah, ed. by juz II qiq Muhammad Fu'ad 'Abd al-Baqi (Beirut: Dar al-Fikr)

Al-Qurthubi, Syamsuddin, Al-Jami' $\mathrm{Li}$ Ahkam Al-Quran (kairo: Dar al-Kutub al-Mishriyyah, 1964), III

Al-Qusyairi, Abdul-Karim, Ar-Risalah AlQusyairiyyah (Bairut: Dar al-Ma'arif), I

At-Tabi'i, Mujahid bin Jabbar, Tafsir Mujahid, ed. by Dr. Muhammad 'Abdus-Salam (Dar al-Fikr alIslamiyyah al-Haditsah, 1989), I 
At-Thibi, Al-Husain bin 'Abdullah, Al-Kasyif 'an Haqaiq as-Sunan (Riyadh: Maktabah Nizar Musthafa al-Baz, 1997), VII

Ibn Baththal al-Maliki, Syarh Shahih AlBukhari (Riyadh: Maktabah ar-Rusyd, 2003), VI

Ibn Duraid, Jamharatul-Lugoh, ed. by Ramzi Munir Ba'labaki (Beirut: Dar 'Ilm lil Malayin, 1987), II

Ibn Hajar al-Asqalaniy, Bulugh Al-Maram Min Adillatil-Ahkam (Riyadh: Dar alFalaq, 1424)

Ibn Mulaqqin as-Syafi'i, At-Taudih Li Syarhi Jami' as-Shahih (Damaskus: Dar anNawadir, 2008), XIV

Ibn Rajab al-Hanbali, Fath Al-Bari Syarh Shahih Al-Bukhari (Madinah: Maktabah al-Ghuraba al-Asariyyah, 1996), III

Ibn Syahin Umar bin Ahmad, Nasikh AlHadis Wa Mansukhihi, ed. by Sumair bin Amin Az-Zuhairi (Maktabah alManar, 1988)

M. Nejatullah Siddiqi, Issues in Islamic Banking: Selected Papers, trans. by Asep Hikmat (Bandung: Pustaka, 1984)

Majma' (Dewan) Lugoh 'Arabiyyah, Mu'jam Al-Wasith. (kairo: Dar ad-Da'wah), I

Muhammad Asad, 'The Message Of The Quran; Translated And Explained'.
Muhammad bin Ismail as-Shan'ani, Subulus Salam (Riyadh: Maktabah al-Ma'arif, 2006), III

Murtadha az-Zubaidi, Taj Al-'Arus (Dar alHidayah), XXXVIII

Muslim bin al-Hajjaj Abu al-Husain alQusyairiy al-Naisaburiy, Shohih Muslim, ed. by Muhammad Fuad Abdul Baqiy (Darr Ihya al-Turats al-Arabiy), III

Philip D. Morehead, The New American Webster Dictionary, 4th edn, 2001

Wahbah az-Zuhaili, Tafsir Al-Munir Fi Al'Aqidah Wa as-Syari'ah Wa Al-Manhaj (Damaskus: Dar al-Fikr al-Mu'ashir, 1418), VI

Yahya bin Salam, Tafsir Yahya Bin Salam, ed. by Dr. Hindun Syalabi (Beirut: Dar al-Kutub al-'Ilmiyah, 2004)

Yusuf Ali, The Holy Qur-an: English Translation of The Meanings and Commentary (Riyadh: King Fahd Holy Quran Printing Complex, 1405)

Zakaria, Abi al-Husain Ahmad Faris bin, Mu'jam Al-Maqayis Fi Al-Lughah, ed. by Abdussalam Muhammad Harun (Beirut: Darr al-Fikr, 1979) 